\title{
Inflammasjon og C-reaktivt protein ved hjerte- og karsykdom
}

\author{
Sammendrag \\ Bakgrunn. Artikkelen belyser den rol- \\ len betennelsesprosesser spiller i \\ utviklingen av aterosklerotisk sykdom \\ og komplikasjoner knyttet til den. Det \\ diskuteres om betennelsesmarkøren \\ høysensitivt C-reaktivt protein (hs- \\ CRP) bør brukes i risikovurderingen.
}

\section{Materiale og metode. Grunnlaget for} artikkelen er et ikke-systematisk litteratursøk i PubMed med et skjønnsmessig utvalg av artikler basert på forfatternes erfaring innen feltet.

Resultater. Både kroniske betennelsessykdommer og akutte infeksjoner er forbundet med økt risiko for hjerteog karhendelser. Influensavaksinasjon reduserer risikoen for iskemiske koronare hendelser hos koronarsyke pasienter, men effekten på kardiovaskulær dødelighet er ikke dokumentert. Hs-CRP er en uavhengig risikomarkør for hjerte- og karsykdom i populasjoner med og uten etablert hjerte- og karsykdom. Personer uten kjent kardiovaskulær sykdom og med normalt kolesterolnivå, men med forhøyet hs-CRPverdi, fikk redusert hs-CRP-nivå og risiko for hjerte- og karsykdom etter behandling med rosuvastatin.

Fortolkning. Personer med kroniske betennelsessykdommer og personer med høy kardiovaskulær risikoprofil og akutt infeksjon er utsatt for kardiovaskulære hendelser og bør vurderes for primærprofylaktiske tiltak. Hos pasientgrupper med moderat forhøyet risikoprofil for hjerte- og karsykdom kan hs-CRP være et verdifullt supplement til etablerte faktorer i risikovurderingen. Til tross for tallrike studier som bekrefter rollen til hs-CRP som uavhengig risikomarkør, har hs-CRP foreløpig ikke funnet sin plass i internasjonale retningslinjer. Disse bør revurderes i lys av nye resultater.

\author{
Peter Scott Munk \\ smpe@sus.no \\ Alf Inge Larsen \\ Hjerteavdelingen \\ Stavanger universitetssykehus \\ 4068 Stavanger \\ og \\ Institutt for Indremedisin \\ Universitetet i Bergen
}

Til tross for betydelige fremskritt innen forskning på aterosklerose og behandling, befinner aterosklerotiske komplikasjoner seg fremdeles på toppen av listen over dødsårsaker i den vestlige verden. I dag betraktes aterosklerose ikke lenger som en ren kolesterolavleiringssykdom, men som en kompleks betennelsessykdom i åreveggen (1).

Både hjerteinfarkt og hjerneslag er komplikasjoner av aterosklerotisk karsykdom, en mangeårig prosess som er preget av endotelial dysfunksjon, fortykkelse av intima, avleiring av lipoproteiner og innvandring og opphopning av betennelsesceller.

Vi belyser den rollen betennelsesprosesser spiller i utviklingen av aterosklerose og medfølgende komplikasjoner og diskuterer om betennelsesmarkøren høysensitivt C-reaktivt protein (hs-CRP) kan brukes i risikovurderingen.

\section{Materiale og metode}

Grunnlaget for artikkelen er et ikke-systematisk litteratursøk i PubMed med et skjønnsmessig utvalg av artikler basert på forfatternes erfaring innen feltet.

\section{Aterosklerose - en betennelsessykdom}

At aterosklerose er en systemisk inflammatorisk sykdom, ble opprinnelig vist i dyremodeller, der fettrik diett førte til binding av monocytter til endotelceller på innsiden av arterier (2). Spesielt områder med periodevis mye blodturbulens er utsatt for utviklingen av aterosklerose (3). Bindingen av betennelsesceller støttes av overflateproteiner kalt adhesjonsmolekyler. Monocyttene vandrer gjennom endotelcellelaget og gjennomgår en forvandling til makrofager, som fagocytterer oksiderte «low density lipoprotein» (LDL)-partikler og apoptotiske cellefragmenter. Opphopning av kolesterol i makrofagenes cytoplasma er kjennetegnet på såkalte skumceller. Aktiverte makrofager presenterer så oksiderte LDL-fragmenter på overflaten, som aktiverer T-lymfocytter. Det oppstår en kaskade av aktivering av immun- kompetente celler med frisetting av inflammatoriske cytokiner, proteaser og celletoksiske radikaler (fig 1) (4). Aktivering av betennelsescellene fører til frisetting av proteolytiske enzymer, cytokiner og vekstfaktorer for glatte muskelceller, som bidrar til utviklingen av plakket. Betennelsescellene er ikke diffust fordelt i plakket, men akkumuleres rundt den fettrike kjernen og i den fibrøse kappen (5). Graden av denne inflammasjonen i det aterosklerotiske plakket bestemmer også risikoen for plakkruptur, som ofte er den tilgrunnliggende prosess for den akutte koronare hendelsen (6). Betennelsen spiller således en sentral rolle $\mathrm{i}$ alle faser av sykdomsprosessen, fra avleiringen av lipider til ruptur av aterosklerotiske plakk med påfølgende trombotiske komplikasjoner (fig 2).

\section{Bindevevssykdommer og inflammasjon}

Det finnes flere eksempler på sammenheng mellom systemisk inflammasjon og inflammasjon i koronarkar. Pasienter med bindevevssykdommer, som revmatoid artritt, har forhøyet hs-CRP-nivå og også økt forekomst av kardiovaskulær sykdom (7). Flere typer betennelsesceller som danner infiltrater $\mathrm{i}$ ledd og leddkapsler hos disse pasientene, kan gjenfinnes i aterosklerotiske plakk (8). Hos pasienter med betent tannkjøtt (periodontitt) er det vist at intensiv mekanisk behandling fører til en akutt kortvarig systemisk inflammasjon med økning av betennelsesmarkører som hs-CRP og en ledsagende endotelial dysfunksjon (9). Behandling av

\section{Hovedbudskap}

- Infeksjoner og akutte betennelsesreaksjoner er forbundet med forbigående $ø k t$ risiko for hjerteinfarkt og hjerneslag

- Selv om influensavaksine reduserer forekomst av iskemiske hendelser hos pasienter med koronarsykdom, er effekten på kardiovaskulær dødelighet ikke tilstrekkelig dokumentert

- Bruken av høysensitivt C-reaktivt protein som risikomarkør for hjerte- og karsykdom er omdiskutert, og gjeldende retningslinjer bør revurderes i lys av nyere studier 


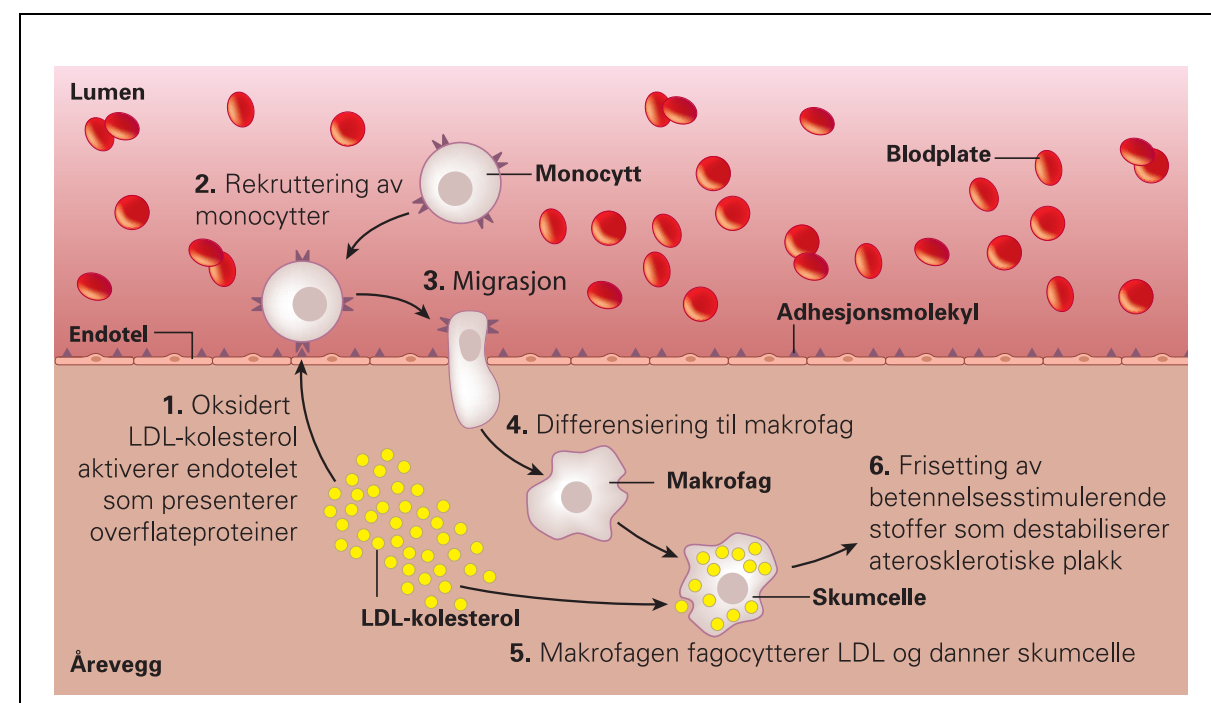

Figur 1 Initiering av inflammasjon i karveggen. Oksidert LDL-kolesterol aktiverer endotelcellene (1), som reagerer med å presentere overflateproteiner på blodsiden (2). Monocytter binder seg til disse adhesjonsmolekylene (3), vandrer gjennom endotelet (4) og gjennomgår en forvandling til makrofager (5). Makrofagene fagocytterer kolesterol og blir til såkalte skumceller. Disse skumcellene spiller en sentral rolle i utviklingen av plakk og frigjør cytokiner og proteaser (6), som virker betennelsesstimulerende og destabiliserer aterosklerotiske plakk. tannkjøttet er i samme studie ledsaget av bedret endotelfunksjon ved to og seks måneders oppfølging.

\section{Infeksjoner og vaksine}

Forekomsten av hjerteinfarkt og hjerneslag varierer sesongavhengig, med høyest forekomst i vintermånedene. I vintersesongen er det også høyere frekvens av øvre luftveisinfeksjoner, som ofte er relatert til influensa. En stor epidemiologisk studie viser at akutte infeksjoner i øvre luftveier gir omtrent fem ganger økt risiko for hjerteinfarkt og tre gan- ger økt risiko for hjerneslag gjennom de første tre dagene, før risikoen avtar gradvis (10). Dette er bekreftet i studier av influensaepidemier der man har vist en samtidig økt forekomst av koronare dødsfall bekreftet ved autopsi under epidemiene (11). Vaksinasjon mot influensa reduserte risikoen for iskemiske koronare hendelser hos pasienter med koronar hjertesykdom i en placebokontrollert randomisert polsk studie med 658 koronarsyke pasienter (12). Imidlertid foreligger det ingen stor nok prospektiv randomisert studie der man kan vurdere effekten av influ-

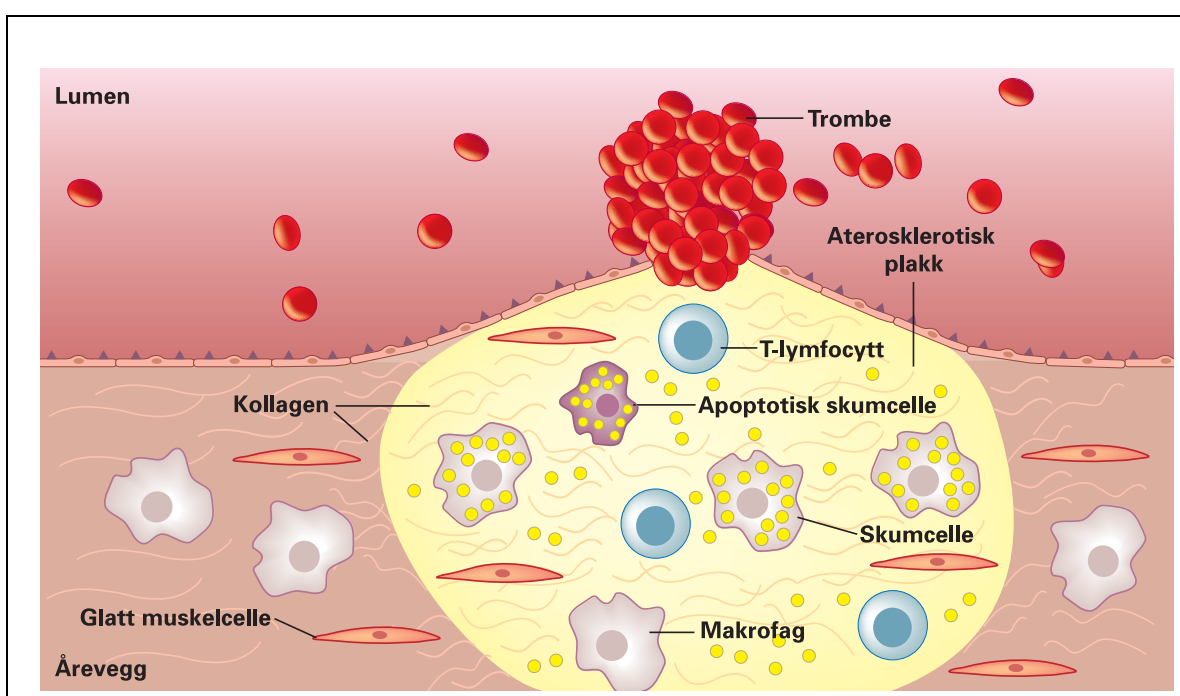

Figur 2 Skjematisk tegning av et «ustabilt plakk» med ruptur og trombose. Skumceller akkumuleres i den fibrøse kappen av et plakk. I et samspill mellom betennelsesceller som makrofager, T-lymfocytter, mastceller, glatte muskelceller, lipider og cytokiner kan det oppstå en rift i endotelet, som fører til at blodet kommer i kontakt med trombogene overflater som aktiviserer det endogene koagulasjonssystemet. Konsekvensen er en trombe, som kan gi iskemiske symptomer. ensavaksine på kardiovaskulær dødelighet i primær- eller sekundærprofylaktisk øyemed.

Mens American Heart Association (AHA) anbefaler influensavaksine for alle pasienter med koronar hjertesykdom (klasse IB-anbefaling) (13), begrenser European Society of Cardiology (ESC) i sine retningslinjer fra 2008 anbefalingen til pasienter med symptomatisk hjertesvikt (klasse IIa Canbefaling) (14).

\section{C-reaktivt protein og hjerte- og karsykdom}

CRP er et akuttfaseprotein som hovedsakelig produseres i leverceller som respons på cytokiner som interleukin-6 og tumornekrosefaktor- $\alpha$ (15). I klinisk arbeid anvendes CRP som en ikke-spesifikk markør for betennelse og vevsskade. Moderne analyseteknikk for CRP med deteksjonsgrenser ned mot $0,1 \mathrm{mg} / 1$ gjør det nå mulig å bruke mikro-CRP eller «high-sensitivity-CRP» (hsCRP) $(\mathrm{CRP}<5-10 \mathrm{mg} / \mathrm{l})$ som markør for kardiovaskulær risiko. CRP har en halveringstid på cirka 20 timer og er relativt stabil over tid med en reproduserbarhet sammenliknbar med blodtrykket eller kolesterolmålinger (16). Mange studier har vist at hsCRP er en uavhengig prediktor for hjerteinfarkt, iskemisk hjerneslag og kardiovaskulær død i populasjoner med og uten etablert hjerte- og karsykdom $(17,18)$. Pasientene kan deles inn i grupper med lav, middels og høy risiko avhengig av hs-CRP-verdier $(<1$, $1-3$, og $>3 \mathrm{mg} / \mathrm{l})$ (19). Man bruker gjennomsnittet av to CRP-målinger, tatt med minst to ukers mellomrom. Ved verdier over $10 \mathrm{mg} / \mathrm{l} \mathrm{skal} \mathrm{testen} \mathrm{gjentas} \mathrm{og} \mathrm{pasienten} \mathrm{un-}$ dersøkes for infeksjon eller inflammasjon (19). Videre kan forhøyet hs-CRP-nivå predikere utviklingen av type 2-diabetes og hypertensjon $(20,21)$ og er assosiert med det metabolske syndrom (18).

Basert på tradisjonelle risikofaktorer i Framingham Risk Score kan man estimere en persons risikonivå for å utvikle hjerte- og karsykdom til lav (0-10 \% tiårsrisiko), middels (10-20\%) og høy (over 20\%) (22). Supplement med hs-CRP-verdi påvirker denne risikostratifiseringen ved en omklassifisering av opptil $30 \%$ av individer med middels høy risiko til klinisk relevante høyere eller lavere risikokategorier. Betydningen av hs-CRP-nivå for risikovurderingen i denne analysen var like stor som LDL-kolesterolnivå, hypertensjon og røyking (23).

I Reykjavik Hjertestudien, en prospektiv undersøkelse som evaluerte nytten av betennelsesmarkører for prediksjon av koronarsykdom, konkludert man på den annen side med at hs-CRP-verdien kun marginalt bidro til risikovurderingen etter justering for etablerte risikofaktorer (16). En posthocanalyse der man delte pasientene inn i grupper tilsvarende CRP-nivåer $>3 \mathrm{mg} / \mathrm{log} \leq 1 \mathrm{mg} / \mathrm{l}$, viste imidlertid en multivariatjustert oddsratio (OR) for gruppen med CRP > $3 \mathrm{mg} / \mathrm{l}$ på 
1,7 (95\% KI 1,4-2,0), sammenliknbar med OR for røyking på 1,8 (95\% KI 1,5-2,0) (24).

\section{Hs-CRP og statiner}

I PROVE-IT-TIMI 22-studien, der man sammenliknet behandlingen med to statiner hos pasienter med akutt koronarsyndrom, så man at pasienter med hs-CRP $\geq 2 \mathrm{mg} / \mathrm{l} \mathrm{had}-$ de en høyere risiko for kardiovaskulære hendelser enn dem med lavere hs-CRP (3,1 versus 2,4 per 100 pasientår). Dette gjaldt også for pasienter som fikk senket LDL-kolesterolnivået under $1,8 \mathrm{mmol} / \mathrm{l}(25)$. Ut ifra denne studien er det foreslått å måle hs-CRP-nivået en måned etter optimal opptitrert kolesterolsenkende behandling for å vurdere eventuelle videre sekundærprofylaktiske tiltak.

I REVERSAL-studien, der man brukte intrakoronar ultralyd for å kvantifisere ateromutbredelsen i koronarkar under behandling med statiner, så man størst tilbakegang av ateromstørrelsen i gruppen som oppnådde både lavt LDL-nivå og lavt hs-CRP-nivå (26). Selv om hs-CRP-verdien er nyttig som uavhengig risikomarkør for nye hendelser, og nivået kan senkes med statiner uavhengig av reduksjonen i LDL-kolesterolnivå, anbefales det ikke å bruke hs-CRP isolert som indikator for å igangsette sekundærprofylaktiske behandlingstiltak (19). Imidlertid bør dette kanskje revurderes i lys av resultatene fra den nylig publiserte JUPITER-studien (Justification for the Use of Statins in Primary Prevention: an Intervention Trial Evaluating Rosuvastatin), som var en internasjonal, placebokontrollert, randomisert multisenterstudie, der 17802 personer (menn $>50$ år og kvinner $>60$ år) uten kjent hjerte- og karsykdom og med lav LDL-kolesterolverdi (< $3,4 \mathrm{mmol} / \mathrm{l}$ ) ble inkludert. Studiedeltakere ble vurdert som risikoindivider for koronar hjertesykdom kun på bakgrunn av forhøyet hs-CRP på $>2 \mathrm{mg} / 1$. Intervensjonen besto av $20 \mathrm{mg}$ av statinet rosuvastatin eller placebo (27). Studien ble avbrutt tidlig, etter en gjennomsnittlig oppfølging på knapt to år, på grunn av en signifikant reduksjon av hjerteog karrelatert sykelighet og dødelighet i behandlingsgruppen. Når det gjelder harde klinisk endepunkter (hjerteinfarkt, hjerneslag eller kardiovaskulær død) var den absolutte og relative risikoreduksjonen på henholdsvis $0,9 \%$ og $47 \%$. Det betyr at 120 friske individer må behandles i to år for å forhindre en klinisk hendelse. Det tilsvarer en kostnad på cirka 300000 amerikanske dollar per hendelse (basert på en pris på 3,45 dollar per rosuvastatintablett).

\section{C-reaktivt protein -}

markør, patogen eller begge deler?

Den fysiologiske rollen til CRP er ikke fullstendig klarlagt, og om den kun er en markør eller deltar direkte i patogenesen av den aterosklerotiske prosess og dens komplikasjoner, er et omdiskutert emne. Infusjon av re- kombinant CRP hos friske individer er vist å føre til en økning av inflammatoriske og protrombogene cytokiner og nedsatt tilgjengelighet av nitrogenoksid (28). CRP aktiverer videre humane endotelceller, som resulterer i økt presentasjon av adhesjonsmolekyler (29). Infundert CRP er også vist å gi økt infarktstørrelse i rotteforsøk, men effekten kunne blokkeres ved å gi en CRP-hemmer (30). In vitro fører CRP til økt produksjon og aktivitet av metalloproteinaser (31), som spiller en viktig rolle i destabiliseringen av aterosklerotiske plakk. Forhøyet hs-CRPnivå er dessuten forbundet med endotelcelledysfunksjon (32) og er høyt korrelert med alle komponenter av det metabolske syndromet (18)

\section{Hs-CRP og retningslinjer}

I retningslinjene til ESC fra 2007 er ikke CRP anbefalt til bruk i risikostratifiseringen i den kliniske hverdag (33). Imidlertid anbefaler man i retningslinjene til ESC om forebygging av kardiovaskulær sykdom fra 2008 å vurdere måling av hs-CRP-nivå hos personer med prematur eller aggressiv kardiovaskulær sykdom (på lik linje med lipoprotein (a), fibrinogen og homocystein) (34). Også American Heart Association anbefaler å bruke hs-CRP-måling i risikovurderingen for koronarsykdom i primærprofylaktisk øyemed som supplement til etablerte risikofaktorer (19).

\section{Hs-CRP i klinisk arbeid}

Det europeiske SCORE-prosjektet (Systematic COronary Risk Evaluation) er en modell for å vurdere tiårsrisiko for kardiovaskulær dødelighet basert på europeiske studier (35). Hs-CRP-verdien kan være nyttig i vurderingen av pasienter med en estimert SCORE-risiko på $\geq 5 \%$, der retningslinjene indikerer igangsettelse av medikamentell behandling som valgfritt. Videre vil hs-CRP-verdi kunne brukes hos høyrisikoindivider $(\geq 5 \%$ risiko etter SCORE) med oppnådd LDL-mål for å vurdere om sekundærprofylaktiske tiltak er tilstrekkelig.

\section{Det manglende bindeledd}

Hvorfor fører betennelse til økt risiko for hjerte- og karsykdom? Det er godt dokumentert at betennelsesprosesser er forbundet med nedsatt funksjon av endotelceller (32). Endotelcellene danner en biologisk aktiv skillevegg mellom blodet og kroppens organer. Denne skilleveggen regulerer muskeltonusen $\mathrm{i}$ arterier og arterioler og forhindrer danning av blodpropp i blodkarene ved å hemme blodplater og betennelsesceller. Nedsatt funksjon av endotelcellene finner man hos pasienter med høy kardiovaskulær risikoprofil basert på tradisjonelle risikofaktorer (36). Såkalt endotelcelledysfunksjon er derfor en direkte årsak til økt fare for iskemi og trombose $\mathrm{i}$ iskemisensitive målorganer som hjerte og hjerne. Betennelse er også en protrombogen tilstand med en forskjøvet likevekt mellom trombose og trombolyse i retning av det førstnevnte. Det er diskutert om infeksjoner kan føre til en lavgradig persisterende betennelsesprosess, men intervensjonsstudier med antibiotika kunne ikke bekrefte denne hypotesen (37). Man antar at lokal inflammasjon med frisetting av betennelsesmarkører har en systemisk proaterogen og protrombogen effekt som virker ved å destabilisere arteriosklerotiske plakk (38). Endotelcellene reagerer på samme måten på dyslipidemi, høyt blodtrykk og hyperglykemi, som på proinflammatoriske cytokiner. Resultatet er en økt ekspresjon av adhesjonsmolekyler, som anses å være et initialt skritt i utviklingen av aterosklerose (17).

\section{Konklusjon}

Mennesker med kroniske betennelsessykdommer som leddgikt eller bindevevssykdommer, har økt risiko for hjerte- og karsykdom. Akutte infeksjoner gir forbigående økt risiko for hjerte- og karhendelser. Vaksinasjon mot influensavirus er forbundet med redusert forekomst av iskemiske koronare hendelser og bør kanskje tilbys eldre pasienter med koronar hjertesykdom.

Det er godt dokumentert at hs-CRP-nivå kan predikere risiko for hjerte- og karsykdom uavhengig av andre etablerte risikofaktorer. JUPITER-studien viser at «friske» personer uten hyperkolesterolemi, men med moderat risiko for hjerte- og karsykdom og hs-CRP $>2 \mathrm{mg} / \mathrm{l}$, profitterer på behandling med rosuvastatin. Retningslinjene bør revurderes i lys av resultatene fra JUPITER-studien.

\section{Oppgitte interessekonflikter: Ingen}

\section{Litteratur}

1. Ross R. Atherosclerosis is an inflammatory disease. Am Heart J 1999; 138: S419-20.

. Mata P. Alonso R, Lopez-Farre A et al. Effect of dietary fat saturation on LDL oxidation and monocyte adhesion to human endothelial cells in vitro. Arterioscler Thromb Vasc Biol 1996; 16: 1347-55.

3. Dai G, Kaazempur-Mofrad MR, Natarajan $\mathrm{S}$ et al. Distinct endothelial phenotypes evoked by arterial waveforms derived from atherosclerosis-susceptible and -resistant regions of human vasculature Proc Natl Acad Sci U S A 2004; 101: 14871-6.

4. Hansson GK. Inflammation, atherosclerosis, and coronary artery disease. N Engl J Med 2005; 352: $1685-95$

5. Virmani R, Kolodgie FD, Burke AP et al. Lessons from sudden coronary death: a comprehensive morphological classification scheme for atherosclerotic lesions. Arterioscler Thromb Vasc Biol 2000; 20: $1262-75$.

6. Libby P. Inflammation in atherosclerosis. Nature 2002; 420: 868-74.

7. Solomon DH, Karlson EW, Rimm EB et al. Cardiovascular morbidity and mortality in women diagnosed with rheumatoid arthritis. Circulation 2003; 107: 1303-7.

8. Choy EH, Panayi GS. Cytokine pathways and joint inflammation in rheumatoid arthritis. N Engl J Med 2001; 344: 907-16.

9. Tonetti MS, D'Aiuto F, Nibali L et al. Treatment of periodontitis and endothelial function. N Engl J Med 2007: 356: 911-20.

10. Smeeth L, Thomas SL, Hall AJ et al. Risk of myocardial infarction and stroke after acute infection or vaccination. N Engl J Med 2004; 351: 2611-8. 
11. Madjid M, Miller CC, Zarubaev VV et al, Influenza epidemics and acute respiratory disease activity are associated with a surge in autopsy-confirmed coronary heart disease death: results from 8 years of autopsies in 34,892 subjects. Eur Heart J 2007; 28: 1205-10.

12. Ciszewski A, Bilinska ZT, Brydak LB et al. Influenza vaccination in secondary prevention from coronary ischaemic events in coronary artery disease: FLUCAD study. Eur Heart J 2008; 11: $1350-8$.

13. Smith SC, Allen J, Blair SN et al. AHA/ACC Guidelines for Secondary Prevention for Patients With Coronary and Other Atherosclerotic Vascular disease: 2006 update. Circulation 2006; 113: 2363-72.

14. Dickstein K, Cohen-Solal A, Filippatos G et al. ESC Guidelines for the diagnosis and treatment of acute and chronic heart failure. Eur Heart J 2008; 29: $2388-442$

15. Kushner I. The phenomenon of the acute phase response. Ann N Y Acad Sci 1982; 389: 39-48.

16. Danesh J, Wheeler JG. Hirschfield GM et al. $\mathrm{C}$-reactive protein and other circulating markers of inflammation in the prediction of coronary heart disease. N Engl J Med 2004; 350: 1387-97.

17. Ridker PM, Hennekens CH, Buring JE. C-reactive protein and other markers of inflammation in the prediction of cardiovascular disease in women. N Engl J Med 2000; 342: 836-43.

18. Libby P, Ridker PM, Maseri A. Inflammation and atherosclerosis. Circulation 2002; 105: 1135-43.

19. Pearson TA, Mensah GA, Alexander RW et al. Markers of inflammation and cardiovascular disease: application to clinical and public health practice: a statement for healthcare professionals from the Centers for Disease Control and Prevention and the American Heart Association. Circulation 2003. 107: 499-511.

20. Pradhan AD, Manson JE, Rifai N et al. C-reactive protein, interleukin 6, and risk of developing type 2 diabetes mellitus. JAMA 2001; 286: 327-34.
21. Sesso HD, Buring JE, Rifai N et al. C-reactive protein and the risk of developing hypertension. JAMA 2003; 290: 2945-51.

22. Executive summary of the third report of the National Cholesterol Education Program (NCEP) expert panel on detection, evaluation, and treatment of high blood cholesterol in adults (Adult Treatment Panel III). JAMA 2001; 285: 2486-97.

23. Cook NR, Buring JE, Ridker PM. The effect of including $\mathrm{C}$-reactive protein in cardiovascular risk prediction models for women. Ann Intern Med 2006; 145: $21-9$

24. Ridker P. C-reactive protein and the prediction of cardiovascular events among those at intermediate risk: moving an inflammatory hypothesis toward consensus. J Am Coll Cardiol. 2007; 49: 2129-38.

25. Ridker PM, Cannon CP, Morrow D et al. C-reactive protein levels and outcomes after statin therapy. N Engl J Med 2005; 352: $20-8$

26. Nissen SE, Tuzcu EM, Schoenhagen $P$ et al. Statin therapy, LDL cholesterol, C-reactive protein, and coronary artery disease. N Engl J Med 2005; 352: $29-38$.

27. Ridker PM, Danielson E, Fonseca FAH et al. Rosuvastatin to prevent vascular events in men and women with elevated C-reactive protein. NEJM 2008: 359: 2195-2207.

28. Scirica BM, Morrow DA. Is C-reactive protein an innocent bystander or proatherogenic culprit? The verdict is still out. Circulation 2006; 113: 2128-34.

29. Pasceri V, Willerson JT, Yeh ET. Direct proinflammatory effect of $\mathrm{C}$-reactive protein on human endothelial cells. Circulation 2000; 102: 2165-8.

30. Pepys MB, Hirschfield GM, Tennent GA et al. Targeting $\mathrm{C}$-reactive protein for the treatment of cardiovascular disease. Nature 2006; 440: 1217-21.

31. Montero I, Orbe J, Varo N et al. C-reactive protein induces matrix metalloproteinase- 1 and -10 in human endothelial cells: implications for clinical and subclinical atherosclerosis. J Am Coll Cardiol 2006; 47: 1369-78.
32. Fichtlscherer S, Rosenberger G, Walter DH et al. Elevated C-reactive protein levels and impaired endothelial vasoreactivity in patients with coronary artery disease. Circulation 2000; 102: 1000-6.

33. Graham I, Atar D, Borch-Johnsen K et al. European guidelines on cardiovascular disease prevention in clinical practice: executive summary. Eur Heart J 2007; 28: 2375-414

34. Graham I, Atar D, Borch-Johnsen K et al. [European practice guidelines on prevention of cardiovascular diseases: executive summary]. G Ital Cardiol (Romel 2008; 9: 11-59.

35. Conroy RM, Pyorala K, Fitzgerald AP et al. Estimation of ten-year risk of fatal cardiovascular disease in Europe: the SCORE project. Eur Heart J 2003, 24: $987-1003$.

36. Chan NN, Colhoun HM, Vallance P. Cardiovascular risk factors as determinants of endotheliumdependent and endothelium-independent vascular reactivity in the general population. J Am Coll Cardiol 2001; 38: 1814-20.

37. Wells BJ, Mainous AG 3rd, Dickerson LM. Antibiotics for the secondary prevention of ischemic heart disease: a meta-analysis of randomized controlled trials. Arch Intern Med 2004; 164: 2156-61.

38. Meier CR, Jick SS, Derby LE et al. Acute respiratory-tract infections and risk of first-time acute myocardial infarction. Lancet 1998; 351: 1467-71.

Manuskriptet ble mottatt 28.6. 2008 og godkjent 12.3. 2009. Medisinsk redaktør Trine B. Haugen 